\title{
Cuzco Miter
}

Maya Stanfield-Mazzi

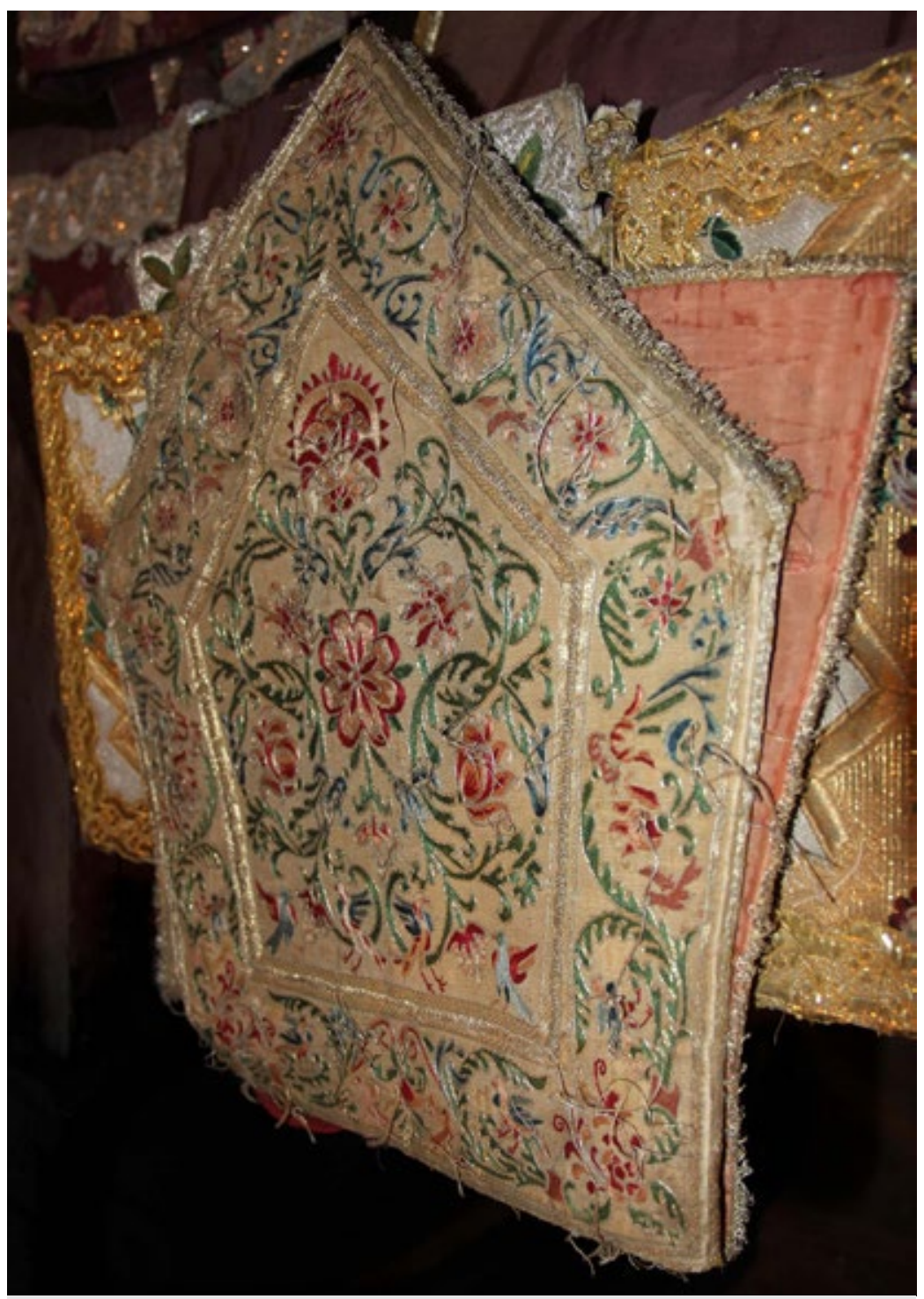

Cuzco Miter, 17th century

The Cathedral of Cuzco, Peru holds several liturgical ornaments from the Spanish colonial period in its treasury. Few, if any, of these items have been published and they have received no scholarly attention. Among them is a magnificent embroidered miter, the headdress worn by bishops for blessings, baptisms, and processions. ${ }^{1}$ The miter owes its form and style to European tradition, but aspects of its preservation, materials, and imagery ground it firmly in Peru and relate to the development of Christianity and Christian art there.

The miter is housed in a modern metal box shaped to fit it, with the lappets ${ }^{2}$ folded 
under. On the box are written the words "de Valverde," in seeming reference to the first bishop of Cuzco and Peru, the Dominican Vicente de Valverde, who first arrived in Cuzco with Francisco Pizarro in 1533. It is unlikely that the miter dates to the sixteenth century, but the attribution suggests that the piece was later seen as physical evidence of Christianity's early history in Peru.

While the materials used to create the miter were probably of European origin, it is possible that the final product was manufactured in Peru. The background for the miter's outer surfaces is a sturdy gold-toned silk; its lining is a lighter coral-colored silk. The outer surfaces are adorned with silk braid (known as galloon) and embroidery in colored silk and silver threads. The silks would have come from southern Spain's silkproducing centers, which flourished in the early colonial period and were protected by the crown. ${ }^{3}$ Galloon was produced widely by Seville's embroiderers and imported to Peru. ${ }^{4}$ The silver threads, created by wrapping silver around gold-toned silk threads, were also likely manufactured in Spain even if the silver was from Peruvian mines. In regard to its final assembly and finishing, however, church account books from seventeenth- and eighteenth-century Cuzco show that church officials seeking liturgical ornaments purchased raw cloth from Spanish merchants and then commissioned the completed products from artisans in Cuzco. ${ }^{5}$ The native Andean author Felipe Guaman Poma de Ayala, writing ca. 1615, described Christianized Andeans employed as embroiderers in Peru. ${ }^{6}$ Spanish immigrants to Peru may also have worked in the embroidery and tailoring trades.

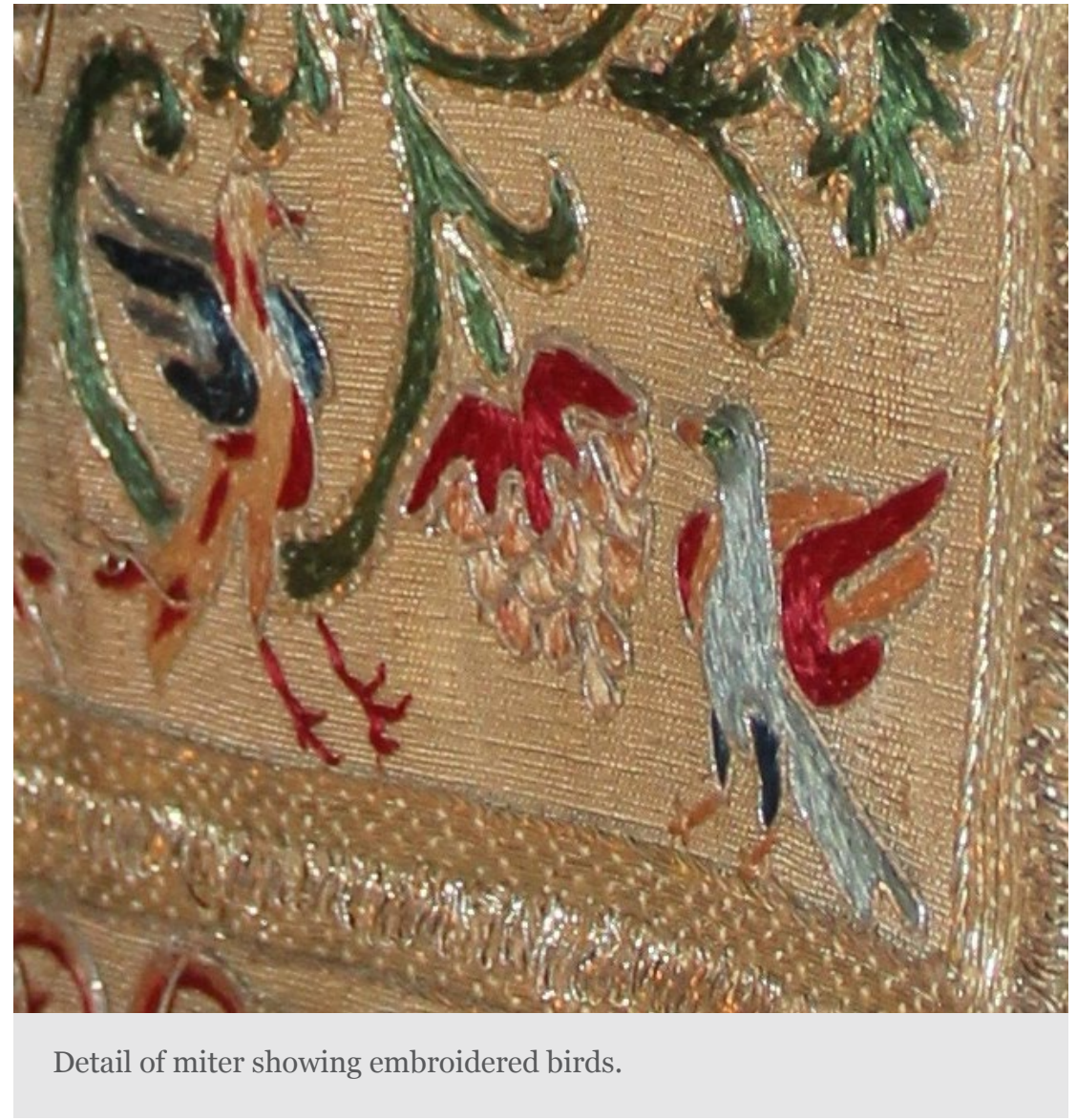


The front of the miter, seen here, features a central field with a wide frame that traces the overall shape of the miter. Similar types of embroidery adorn the frame and the field, namely narrow scrolling plants with flowers, amongst which are interspersed slender multicolored birds. The main field features a large flower in the center, perhaps evoking a chrysanthemum. At the field's apex is a composite image that refers to European motifs of both a pomegranate and an artichoke. The birds at the bottom of this central field stand near red and pink forms akin to clusters of grapes. Most of the imagery seems drawn from European design vocabulary. The grapes and possible pomegranate would have symbolized the blood of Christ and his resurrection, respectively. ${ }^{7}$ The birds suggest a paradisiacal setting and thus evoke the Christian promise of a pleasant afterlife, offered to believers in exchange for Jesus' sacrifice. Richly colored exotic birds became a common feature in works from the Cuzco school of painting during the later seventeenth century. Birds such as hummingbirds and parrots appear in Christian scenes as representatives of heavenly beings and as markers of earthly status. ${ }^{8}$ They appear in paintings that depict processions for Corpus Christi, a festival that celebrated the body and blood of Christ. It is conceivable that Cuzco's bishops would have worn this miter in actual Corpus Christi processions. ${ }^{9}$ In that case, this work can be seen as appealing to, and perhaps even informing, Christian Cuzco's preference for avian imagery.

Stylistically, the miter's decoration is quite similar to that of a feather covered miter that was sent from Mexico to the church of Santa Maria in Vallicella (Rome), also in the seventeenth century. ${ }^{10}$ That miter (with a matching chasuble) features similar arrangements of scrolling vines capped with flowers. In Mexico feathered panels were made using the plumage of a great variety of naturally colored birds, many with local significance. ${ }^{11}$ The presence of real feathers on the Mexican miter would seem to reduce the need for bird imagery, since celestial associations are made with the feathers themselves. The fact that church authorities saw fit to commission the feathered miter from indigenous artisans in Mexico, as were others in the previous century, further supports the possibility that the Cuzco miter was indeed made in Peru. Both pieces thus become examples of local artisanry adapting to the demands of the Catholic church. Ultimately, this the Cuzco piece, which would have been worn by the city's highest religious official on public occasions, should be considered an important aspect of the city's colonial period Catholic visual and material culture.

\section{(C) Maya Stanfield-Mazzi}

\section{Citation Guide}

1. Maya Stanfield-Mazzi, "Cuzco Miter," Object Narrative, in Conversations: An Online Journal of the Center for the Study of Material and Visual Cultures of Religion (2014), doi:10.22332/con.obj.2014.30

Stanfield-Mazzi, Maya. "Cuzco Miter." Object Narrative. In Conversations: An Online Journal of the Center for the Study of Material and Visual Cultures of Religion (2014). doi:10.22332/con.obj.2014.30 


\section{Notes}

1. Christa C. Mayer Thurman, Raiment for the Lord's Service: A Thousand Years of Western Vestments (Chicago: Art Institute, 1975), 34.

2. Lappets are long rectangular flaps that hang down from either side of the back of the headdress.

3. Elena Phipps, "Cumbi to Tapestry: Collection, Innovation, and Transformation of the Colonial Andean Tapestry Tradition," in The Colonial Andes Tapestries and Silverwork, 1530-1830, eds. Elena Phipps, Johanna Hecht and Cristina Esteras Martín (New York: The Metropolitan Museum of Art, 2004), 80-81.

4. Vicente Clavero and José Fernández Martínez, Arte y artesanos de la semana santa de Sevilla, Vol. 7 (Seville: El Correo de Andalucía, 2000).

5. Cf. Archivo del Arzobispado del Cusco, Fábrica e Inventarios, Calca, 1613, 29v. In this case an artisan is contracted to make a cloth altar frontal and is referred to as an "indio sedero," or Indian silk worker.

6. Felipe Guaman Poma de Ayala, Rolena Adorno and Ivan Boserup, "GKS $22324^{\circ}$ : Guaman Poma, Nueva Corónica y Buen Gobierno (1615)," Royal Library of Copenhagen, http://www.kb.dk/permalink/2006/poma/info/en/frontpage.htm (accessed 06/24, 2010).

7. Jennifer Speake, The Dent Dictionary of Symbols in Christian Art (London: J.M. Dent, 1994).

8. Ramón Mujica Pinilla, Ángeles apócrifos en la América virreinal (Mexico City: Fondo de Cultura Económica, 1996); Teresa Gisbert, El paraíso de los pájaros parlantes: La imagen del otro en la cultura andina (La Paz: Plural Editores, Universidad Nuestra Señora de La Paz, 1999); Carolyn Dean, Inka Bodies and the Body of Christ: Corpus Christi in Colonial Cuzco, Peru (Durham, NC: Duke University Press, 1999), 171.

9. The Corpus Christi paintings show a white miter adorned with gold being carried behind the bishop. Cf. Dean, Inka Bodies and the Body of Christ, Plate V.

10. Teresa Castelló Yturbide and Manuel Cortina Portilla, The Art of Featherwork in Mexico (Mexico City: Fomento Cultural Banamex, A.C., 1993), 97.

11. The white feathers that make up the background on the Mexican miter may be from a duck or egret. The red and yellow feathers that form the flowers might be those of the red spoonbill and troupial, respectively, while the green feathers creating the vines could be from any number of green birds, including the quetzal. Bernardino de Sahagún, The Florentine Codex: General History of the Things of New Spain, trans. and ed. by Arthur 
J. O. Anderson and Charles E. Dibble (Santa Fe, N.M.; Salt Lake City, Utah: School of American Research; University of Utah, 1950), 9: 90. For the Mesoamerican significance of the green feathers of the quetzal, see Karl Taube, "The Olmec Maize God: The Face of Corn in Formative Mesoamerica." Res 29/30, (1996): 39-81.

\section{Yale}

Copyright 2016 Yale University All rights reserved. 